\title{
Т.Д. Соколова
}

\section{О ЛОЖНЫХ ДИХОТОМИЯХ: ОТВЕТ А.Л. НИКИФОРОВУ}

\begin{abstract}
Критикуются выдвинутые А.Л. Никифоровым утверждения о целях и результатах развития науки Нового времени. Основной контраргумент заключается в том, что противопоставление «науки как поиска истины» и «науки как развития технологий» является теоретически несостоятельным, так как приводит к ложной дихотомии, основанной на подмене тезиса.

Ключевые слова: наука, история науки, философия науки.
\end{abstract}

В статье «Что дала человеку наука Нового времени?» (2018) А.Л. Никифоров в свойственной ему манере предлагает вниманию читателя несколько утверждений, касающихся развития научно-технического прогресса и его роли в общественной жизни. Некоторые из этих утверждений можно охарактеризовать как радикальные, другие - как тривиальные, а еще несколько - как явные преувеличения. Первые два тезиса, выдвинутые А.Л. Никифоровым, принадлежат сфере эпистемологии и философии науки и поэтому затрагивают предмет моих научных интересов [1. С. 23-57], последний же тезис принадлежит скорее сфере этики и социальной философии. Не будучи специалистом по этическим вопросам, я воздержусь от подробного рассмотрения последнего тезиса, однако в силу того, что этот тезис выводится из двух предыдущих, оставить его без внимания все же не представляется возможным.

Основной проблемой данного текста, на мой взгляд, является неявная подмена тезиса при обсуждении исходного вопроса. Исходный вопрос «Что наука Нового времени дала человечеству?» сначала подменяется вопросом о целях и природе научного познания вообще, затем о фактическом социальном существовании и функционировании науки, потом автор приводит некоторые технические достижения научного прогресса (игнорируя фундаментальные теории его же), объявляет развитие техники причиной формирования общества потребления, а заканчивает (возвращаясь к исходному вопросу) выводом о том, что наука Нового времени никак не повлияла на «духовность человека». При этом что же такое эта самая духовность, тождественна ли она восприимчивости к этическим или эстетическим нормам, образованности или условной «культурности» или представляет собой нечто совершенно иное и специфическое, автор не объясняет. Несостоятельность данной цепочки рассуждений я и попробую обосновать, обращаясь к ее отдельным положениям.

Начинает свое рассуждение А.Л. Никифоров с обозначения цеели научного познания в том виде, в котором ее формулировали некоторые ученые (пусть и философствующие), а также некоторые философы (не являющиеся учеными). Эта благородная цель науки или научной деятельности - поиск истинных и объективных сведений об окружающем мире. Стоит отметить, что данное определение никак не характеризует результаты научной дея- 
тельности ни для самих ученых, ни для общества. Аналогичным образом целью получения высшего образования может быть устройство на высокооплачиваемую работу, а результатом - разочарование и головная боль. Тем не менее определение науки как незаинтересованного поиска истины вполне имеет право на существование хотя бы потому, что в отличие от различных социологических подходов к исследованию научного познания оно пытается очертить некий абстрактный и не всегда выполнимый идеал научной деятельности, т.е. определить «научность» науки вне зависимости от социальных институтов, экономических реалий, политических потрясений и прочих неинтересных для ученого вещей (если, конечно, он не социолог, экономист или политолог).

Следующий теоретический шаг А.Л. Никифорова - довольно тривиальное наблюдение, что наука существует в обществе. С этим трудно поспорить, тем не менее однозначно утверждать, что именно общество (пусть и в лице его отдельных членов и институтов) формирует некий запрос на деятельность ученого, на мой взгляд, все же нельзя [1. С. 23-57]. История науки знает массу примеров того, что научные открытия оставались невостребованными на протяжении многих лет и только позднее благодаря той же деятельности ученых и им сочувствующих стали использоваться на общественное благо. Можно найти примеры того, когда ученые работали по государственному или промышленному заказу [2. С. 8-17]. Есть и примеры, когда теоретические и прикладные исследования производились параллельно ${ }^{1}$. Если же обратиться к более близкой к нам современной ситуации, то этот тезис фальсифицируется процедурой подачи грантовых заявок. Несмотря на наличие закрытого перечня приоритетных направлений исследований, задача ученого, подающего на грант, заключается в том, чтобы убедить экспертный совет фонда (по сути, своих собственных коллег), что его исследование нужно, важно и к тому же осуществимо. Так что в данном случае можно говорить скорее о некоем диалоге, нежели просто об ответе ученого на конкретный общественный запрос. Кроме того, если речь идет об абстрактном улучшении качества жизни, то точно так же можно сказать, что и религия отвечает на общественный запрос, предлагая универсальную инструкцию по спасению души посредством выполнения определенных ритуалов. Тем не менее даже в плоскости изучения науки как социального феномена (а не как познавательного идеала) такой подход можно охарактеризовать как наивный редукционизм, так как он сводит всю сложность социальных феноменов как со стороны общественной роли и существования науки, так и со стороны общественной потребности в науке к довольно примитивной формуле из двух компонентов: деньги в обмен на технологии.

Картина, которую нам представляет А.Л. Никифоров, перечисляя достижения научно-технического прогресса, а также связывая их с удовлетворени-

\footnotetext{
${ }^{1}$ Компактным примером такого события можно считать египетский поход Наполеона.Ученые (а также художники), принимавшие в нем участие, не только проводили те исследования, которые были бы полезны непосредственно для военных операций, но проводили изыскания и в области истории, археологии, филологии, ботаники и т.д., которые вряд ли могли чем-либо помочь амбициозному генералу. Результаты этих исследований зафиксированы в № 1-4 журнала LaDécadeégyptienne, Journal littéraire et d'économie politique, а также фундаментальном многотомном труде Description de l'Égypte, ou Recueil deso bservations et des recherches qui ont été faites en Égypte pendant l'expédition de l'Armée française.
} 
ем «биологических потребностей», выглядит весьма однобоко. Во-первых, в силу того, что игнорируется развитие гуманитарных и социальных наук (психологии, истории, политологии, социологии, экономики, педагогики, да и самой философии), изменение в связи с этим политической ситуации, общественных нравов, представлений о ценностях и т.д. Во-вторых, история человечества еще не завершилась, поэтому называть «общество потребления» последним этапом развития человечества, на мой взгляд, все же преждевременно. Футурологические исследования, посвященные влиянию информационных технологий на развитие общества, экономике пост-труда и прочим последствиям развития научно-технического прогресса, рассматривают современное состояние общества как промежуточный этап, а не как конец света.

Утверждение о том, что поиск истины для ученого Нового времени (равно как и для современного ученого) являлся лишь побочным продуктом осуществления основной задачи - «разработки новых технологий для удовлетворения общественных потребностей» представляется попыткой построить иерархию научных задач на основании довольно шатких принципов. История науки (как и любая другая история) содержит в себе различные факты, из которых, как из кусочков пазла, исследователь может построить любую картину событий, удовлетворяющую практически любой его запрос. Безусловно, со времен Античности научные исследования были тесно связаны с техническим прогрессом. Но что дает нам основание полагать, что именно технический прогресс, а не поиск истины изначально является главной задачей науки [3. С. 6875]? Насколько корректно противопоставлять эти цели и утверждать, что одна из них основная, а другая - побочный продукт? В конце концов, еще Аристотель, проводя различие между искусством и ремеслом, писал: «А после того как было открыто больше искусств, одни - для удовлетворения необходимых потребностей, другие - для времяпрепровождения, изобретателей последних мы всегда считаем более мудрыми, нежели изобретателей первых, так как их знания были обращены не на получение выгоды. Поэтому, когда все такие искусства были созданы, тогда были приобретены знания не для удовольствия и не для удовлетворения необходимых потребностей, и прежде всего в тех местностях, где люди имели досуг» [4. Т. 1. С. 67]. На мой взгляд, пытаясь противопоставить науку как поиск истины и науку как создание технологий [5. С. 40-44], А.Л. Никифоров упускает из вида, что это две стороны одного и того же процесса.

И наконец, пессимистичный вывод о том, что использование Интернета не делает людей лучше, основанный на предыдущих рассуждениях о природе и функциях науки, выглядит по меньшей мере странно. Во-первых, ни определение науки как поиска истины, ни определение ее же как технонауки не предполагает морально-нравственной составляющей. Во-вторых, обращение к искусству или религии не является панацеей от аморального поведения. «Евгения Онегина» в школе читали все, в том числе и осужденные по статье 105 УК РФ «Убийство». Обвинять науку в том, что она вложила смартфоны нам в руки (видимо, для удовлетворения биологических потребностей в получении информации и общении), но не позаботилась о наших бессмертных душах, само по себе нелепо. Хотя бы потому, что наука отказалась от понятия «душа», заменив его понятием «психика». А психику наука способна улучшить, это научный факт. 


\section{Лumepamypa}

1. Sokolova et al. Communications in Science: Epistemological, Socio-cultural and Infrastructural Aspects. Materials of the Round Table // Voprosy filosofii. 2017. Iss. 11. P. $23-57$.

2. Аристотель. Метафизика // Соч. : в 4 т. М., 1976. Т. 1. С. 64-367.

3. Kasavin I.T. A. Trading zones as a subject-matter of social philosophy of science // Epistemology and Philosophy of Science. Vol. 51, Iss. 1. P. 8-17.

4. Antonovski A.Yu. Social Philosophy of Science as the Gardian of the "Incarnation of truth in the World" // Epistemology \& Philosophy of Science. 2017. Vol. 51, Iss. 1. P. 68-75.

5. Stoliarova O.E. Technoscience as an Experimental Environment and Experimental Methodology // Epistemology \& Philosophy of Science. 2016. Vol. 48, Iss. 2. P. 40-44.

Tatiana D. Sokolova, Institute of Philosophy, Russian Academy of Science (Moscow, Russian Federation).

E-mail: sokolovatd@gmail.com

Vestnik Tomskogo gosudarstvennogo universiteta. Filosofiya. Sotsiologiya. Politologiya - Tomsk State University Journal of Philosophy, Sociology and Political Science. 2018. 42. pp. 197-200.

DOI: $10.17223 / 1998863 \mathrm{X} / 42 / 22$

ON FALSE DICHOTOMIES: A REPLY TO ALEXANDER NIKIFOROV

Keywords: science; history of science; philosophy of science.

In the article, the author criticizes the thesis by Alexander Nikiforov on the role of modern science in the contemporary world. The author's first claim consists in denying Nikiforov's contradistinction between "science as search for truth" and "science as technological development". First of all, this contradistinction leads towards a false hierarchy of disciplines whose subject of investigation is science, i.e. philosophy of science, history of science, sociology of knowledge, etc. By defining the "true nature and purpose" of science as technological development, Nikiforov either rejects or oppresses other definitions and ways of investigation, the philosophical one included. Further, this contradistinction does not take into account the fact that fundamental scientific theories have existed and still exist without a necessary development of technologies, so it can hardly be said that science per se is just a way to make gadgets for satisfying human needs. Though the simplicity of this dualistic approach may seem to be quite appealing, its theoretical benefits (especially for epistemology) are questionable. The development of fundamental science and the socalled "technoscience" are the results of a single process, i.e. general scientific development. That is why they cannot be considered as two opposite phenomena. The author's second claim covers the lack of Nikiforov's attention to the contribution by social sciences and the humanities to science in general: these disciplines do not create any technologies in the sense of tools or gadgets, but their development successfully influenced societies in their political structure, social policies and civil rights, especially in the First World countries. Then the author argues that some concepts by Nikiforov like "biological needs" or "spirituality" are opaque and their link to scientific development is groundless. Finally, the author claims that the very answer to the initial question on the moral value of science is incorrect, because it is based on the substitution of the thesis.

\section{References}

1. Pruzhinin, B.I. et al. (2017) Communications in Science: Epistemological, Socio-cultural and Infra-structural Aspects. Materials of the Round Table. Voprosy filosofii. 11. pp. 23-57. (In Russian).

2. Aristotle. (1976) Sochineniya v 4 t. [Works in 4 vols]. Vol. 1. Translated from Ancient Greek. Moscow: Nauka. pp. 64-367.

3. Kasavin, I.T. (2017) Trading zones as a subject-matter of social philosophy of science. Epistemologiya i filosofiya nauki-Epistemology \& Philosophy of Science. 51(1). pp. 8-17. (In Russian). DOI: $10.5840 /$ eps20175111.

4. Antonovskiy, A.Yu. (2017) Social Philosophy of Science as the Guardian of the "Incarnation of Truth in the World". Epistemologiya i filosofiya nauki - Epistemology \& Philosophy of Science. 51(1). pp. 68-75. (In Russian). DOI: 10.5840/eps201751110

5. Stoliarova, O.E. (2016) Technoscience as an Experimental Environment and Experimental Methodology. Epistemologiya i filosofiya nauki - Epistemology \& Philosophy of Science. 48(2). pp. 40-44. (In Russian). 